\title{
Minimally invasive surgical approach to retrieve migrated intrauterine contraceptive device
}

\author{
Maruti Sinha $^{1}$, Ridhima Gupta $^{2}$, Aruna Tiwari ${ }^{1}$ \\ ${ }^{1}$ Department of Obstetrics and Gynecology, Kasturba Hospital, Darya Ganj, New Delhi- 110002, India \\ ${ }^{2}$ Department of Obstetrics and Gynecology, Lutheran Medical Center, Brooklyn, New York- 11209, USA
}

Received: 5 February 2013

Accepted: 22 March 2013

\author{
*Correspondence: \\ Dr. Ridhima Gupta, \\ E-mail: ridhimagupta.04@gmail.com
}

(C) 2013 Sinha M et al. This is an open-access article distributed under the terms of the Creative Commons Attribution License, which permits unrestricted use, distribution, and reproduction in any medium, provided the original work is properly cited.

\begin{abstract}
Background: To present experience with clinical presentation, diagnosis and minimally invasive removal of migrated intrauterine contraceptive device (IUD).

Methods: A total of 6 patients were included in retrospective study. Diagnosis was based on clinical presentation, TVS and Abdominopelvic X- ray. Minimally invasive approach was utilized to remove migrated IUD.

Results: The mean (range) age of the patient was 36.6 (26-55) years. The mean (range) of parity was 3.5 (2-6). The mean (range) duration of IUD use was 8.1 (3-25) years. Five patients had TCu380A IUD. One patient had Lippes loop type of IUD. Three patients underwent laparoscopy, two had hysteroscopy and one had cystoscopy, for removal of IUD. The mean (range) operative time was 40.8 (18-76) mins. No anesthesia or surgery related complications were observed intraoperatively. The mean (range) duration of hospital stay was 34 (24-48) hours. The postoperative course was uneventful and all the patients were followed for 3-6 months period of time with no complaints.

Conclusion: Removal of migrated IUDs is recommended in symptomatic and asymptomatic patients using minimally invasive approach.
\end{abstract}

Keywords: Laparoscopy, Hysteroscopy, Cystoscopy, Intrauterine contraceptive device, Uterine perforation

\section{INTRODUCTION}

Intrauterine devices (IUD) are popular, safe and convenient methods of long term reversible birth control. It is estimated that 100 million women worldwide are using IUD and it constitutes the most prevalent form of contraception method in India, after female sterilization. ${ }^{1}$ Over the years multiple types of intrauterine devices (IUDs) were introduced and currently, most commonly used IUDs include TCu380A and levonorgesterol (Mirena) IUD.

Various complications of IUDs include bleeding, infection, ectopic pregnancy and uterine perforation. Incidence of uterine perforation by an IUD, is reported to range from $0-1.3$ per 1000 insertions. ${ }^{2}$ IUD can erode the uterine wall and can migrate into adjacent pelvic structures like the bladder, bowel, peritoneum and appendix. ${ }^{3}$ A case of migration of IUD even into iliac veins has been reported. ${ }^{4}$ Such an event leads to tissue destruction, peritonitis, adhesion formation, intestinal obstruction and infertility. Diagnosis of migrated IUD is usually suspected in cases of unexplained lower abdominal pain and non-visualization of IUD string on speculum examination. ${ }^{5}$

Surgical removal of displaced symptomatic IUD should be performed using minimally invasive approach. Herein, we report our experience with clinical presentation, diagnosis and management of six patients who presented with misplaced IUD. 


\section{METHODS}

A total of 6 patients were diagnosed with migrated IUD at Department of Obstetrics and Gynecology, Kasturba hospital, New Delhi, India and were included in the retrospective analysis. The study was approved by ethical committee of Kasturba Hospital. The charts of six patients were analysed and the data regarding, demographic characters, clinical presentation, duration of IUD use, type of IUD, diagnostic imaging and operative details was studied. At initial presentation, all the patients presented with non visualization of IUD thread at cervical os and varied clinical sign and symptoms. Diagnosis of lost IUD was made after transvaginal sonogram (TVS) demonstrated complete or partial absence of IUD from the uterine cavity. Abdominopelvic $\mathrm{X}$ - ray in anteroposterior and lateral views were additionally obtained to confirm extrauterine location of IUD. Minimally invasive approach was utilized in all the patients to remove migrated IUD. All the procedures were performed under general anesthesia. Dense adhesions were encountered during removal of IUD and adhesiolysis was done when required, endoscopically.

\section{RESULTS}

The mean (range) age of the patient was 36.6 (26-55) years. The mean (range) of parity was 3.5 (2-6). The mean (range) duration of IUD use was 8.1 (3-25) years. The demographic characters, clinical presentation, duration of IUD use, type of IUD and diagnostic imaging of all the patients are described in Table 1. Three patients had IUD inserted in their postpartum period, 4-6 weeks after delivery. Five patients had IUD of TCu380A type. Only one patient (case 4) had Lippes loop type of IUD inserted 25 years ago. At initial presentation, all the patients presented with nonvisualization of IUD thread at cervical os with highly variable different clinical signs and symptoms. One patient was pregnant and presented with hyperemesis gravidarum. Patient with IUD migrated to urinary bladder, presented with hematuria, dysuria, burning micturition and high grade fever suggestive of urinary tract infection. Other presentations include, postmenopausal bleeding, menometrorrhagia and chronic pelvic pain. Definitive diagnosis of misplaced IUD was obtained by performing TVS and abdominopelvic X-ray in all patients.

Table 1: Demographic profile of patients.

\begin{tabular}{|c|c|c|c|c|c|c|c|}
\hline Case (no.) & Age (years) & Parity & $\begin{array}{l}\text { Duration } \\
\text { of IUD use }\end{array}$ & Presentation & Diagnosis & $\begin{array}{l}\text { Type of } \\
\text { IUD }\end{array}$ & Comments \\
\hline 1 & 26 & 6 & 4 & $\begin{array}{l}\text { UTI, high grade } \\
\text { fever }\end{array}$ & TVS, X-ray & TCu380A & \\
\hline 2 & 30 & 2 & 3 & $\begin{array}{l}\text { Amenorrhea, } \\
\text { lower abdominal } \\
\text { pain }\end{array}$ & TVS, X-ray & TCu380A & \\
\hline 3 & 30 & 3 & 5 & $\begin{array}{l}\text { Pregnancy with } \\
\text { hyperemesis } \\
\text { gravidarum }\end{array}$ & TVS, X-ray & TCu380A & $\begin{array}{l}\text { Incidental } \\
\text { undesired } \\
\text { pregnancy }\end{array}$ \\
\hline 4 & 55 & 6 & 25 & $\begin{array}{l}\text { Postmenopausal } \\
\text { bleeding }\end{array}$ & TVS, X-ray & Lippes loop & \\
\hline 5 & 32 & 2 & 3 & $\begin{array}{l}\text { Chronic pelvic } \\
\text { pain }\end{array}$ & TVS, X-ray & TCu380A & \\
\hline 6 & 47 & 2 & 9 & Menometrorrhagia & TVS, X-ray & TCu380A & \\
\hline
\end{tabular}

The operative characteristics of the patients are described in Table 2. All the patients underwent minimally invasive technique, laparoscopy (n-3), hysteroscopy (n-2) and cystoscopy (n-1) for removal of IUD. The site of uterine perforation was identified in 3 patients. IUDs were found to be located in urinary bladder (n-1), posterior cul-de sac (n-1), right ovarian fossa (n-1), deeply buried in myometrium (n-2) and in one patient (case 2), it was lying in intra-abdominal cavity near uterine fundus.

Dense omental and small bowel adhesions were present in three patients surrounding IUD's, which were resected laparoscopically to retrieve IUD. Intrauterine adhesions were present in 2 patients requiring hysteroscopic resection. The pregnant patient (case 3), requested termination of pregnancy as this was an undesired conception. Medical induction was started with prostaglandins, which failed. Patient then underwent dilatation and evacuation for termination of pregnancy followed by removal of IUD laparoscopically. Patient with Lippes loop in-situ (case 4), only had broken piece of loop near internal cervical os surrounded by dense fibrosis. Patient reports at she had removal of her IUD after few months of insertion due to menometrorrhagia. But she was not informed of any breakage or incomplete removal of Lippes loop. 
Table 2: Intraoperative characters of the patients.

\begin{tabular}{|c|c|c|c|c|c|c|}
\hline $\begin{array}{l}\text { Operative } \\
\text { parameter }\end{array}$ & Case 1 & Case 2 & Case 3 & Case 4 & Case 5 & Case 6 \\
\hline Procedure & Cystoscopy & Laparoscopy & Laparoscopy & Hysteroscopy & Laparoscopy & Hysteroscopy \\
\hline Perforation site & $\begin{array}{c}\text { Not } \\
\text { identified }\end{array}$ & Fundus & $\begin{array}{c}\text { Posterior } \\
\text { uterine wall }\end{array}$ & Not identified & $\begin{array}{l}\text { Lateral uterine } \\
\text { wall }\end{array}$ & Not identified \\
\hline $\begin{array}{l}\text { Location of } \\
\text { IUD }\end{array}$ & $\begin{array}{l}\text { Urinary } \\
\text { bladder }\end{array}$ & $\begin{array}{l}\text { Intraabdoinal } \\
\text { cavity }\end{array}$ & $\begin{array}{c}\text { Posterior cul } \\
\text { de sac }\end{array}$ & Myometrium & $\begin{array}{l}\text { Right ovarian } \\
\text { fossa }\end{array}$ & Myometrium \\
\hline Adhesions & None & Omental & $\begin{array}{c}\text { Omental and } \\
\text { Bowel }\end{array}$ & $\begin{array}{c}\text { Multiple } \\
\text { intrauterine }\end{array}$ & $\begin{array}{l}\text { Omental, bowel } \\
\text { and posterior } \\
\text { abdominal wall }\end{array}$ & Internal OS \\
\hline $\begin{array}{l}\text { Operative time } \\
\text { (mins) }\end{array}$ & 25 & 44 & 62 & 18 & 76 & 20 \\
\hline Complications & None & None & None & None & None & None \\
\hline $\begin{array}{c}\text { Duration of } \\
\text { hospital } \\
\text { stay(hrs) }\end{array}$ & 36 & 24 & 48 & 24 & 48 & 24 \\
\hline $\begin{array}{l}\text { Follow up } \\
\text { (months) }\end{array}$ & 6 & 6 & 6 & 3 & 6 & 3 \\
\hline Comments & $\begin{array}{c}\text { I/V } \\
\text { antibiotics } \\
\text { was given } \\
\text { Intraoperati } \\
\text { vely }\end{array}$ & $\begin{array}{l}\text { Adhesiolysis- } \\
\text { is was } \\
\text { performed }\end{array}$ & $\begin{array}{l}\text { Failed MTP, } \\
\text { D\&E for } \\
\text { TOP, } \\
\text { Adhesiolysis } \\
\text { was } \\
\text { performed }\end{array}$ & $\begin{array}{l}\text { Intrauterine } \\
\text { adhesiolysis } \\
\text { was } \\
\text { performed }\end{array}$ & $\begin{array}{l}\text { Adhesiolysis was } \\
\text { performed }\end{array}$ & $\begin{array}{c}\text { Dense fibrosis } \\
\text { near internal OS }\end{array}$ \\
\hline
\end{tabular}

The mean (range) operative time was 40.8 (18-76) mins. No anesthesia or surgery related complications were observed intraoperatively. The mean (range) duration of hospital stay was 34 (24-48) hours. The postoperative course was uneventful and all the patients were discharged home in stable condition. One patient (case 1) who initially presented with urinary tract infection, was started on preoperative intravenous antibiotics and was discharged home on oral antibiotics. Postoperatively, all the patients were followed for 3-6 months period of time with no complaints.

\section{DISCUSSION}

IUD is generally considered highly effective and safest modality of contraception. Failure to locate the threads of an IUD may indicate either expulsion of device, or presence of IUD in uterine cavity with threads folded inside, or migration outside the uterine cavity after perforating the uterine wall.

Majority of perforation occur during the time of insertion especially by inexperienced hands. As indicated in our study, patient may remain asymptomatic for years after initial insertion, before presenting with sign and symptoms suggestive of migration of device. Timing of IUD insertion is also important factor contributing of uterine perforation. Insertion performed in the post partum period, while women are lactating is associated with 10 times higher risk of uterine perforation and 2.3 times greater risk of incarceration. ${ }^{6}$ Three patients in our study had post partum insertion of IUD. The possible mechanisms responsible for migration of IUDs are uterine contractions, endometrial atrophy and chronic inflammation to copper containing foreign body with gradual erosion through uterine wall. ${ }^{7}$

Diagnostic imaging with plain radiograph of the abdomen and pelvis and transvaginal sonogram, plays a crucial role in evaluation and diagnosis of misplaced IUDs. CT scan is also recommended for exact localization and guided removal of the device. ${ }^{8}$

Management of an intra-abdominal mislocated IUD is controversial. Studies in the past have reported that removal of an IUD from abdomen after perforation is not 
mandatory. ${ }^{10}$ Markovitch et al, also recommended that aymptomatic patients may benefit from noninterventional conservative management. ${ }^{5}$ In contrast, World Health organization guidelines recommend that misplaced IUDs should always be removed as soon as possible after diagnosis is established regardless of its type and location. ${ }^{10}$ The main reason for these recommendations is their potential for extensive adhesion formation, further resulting in complications like bowel obstruction, chronic pelvic pain and infertility. Additionally, migration of misplaced IUD to adjacent structures like bladder, bowel and ovary may compromise their normal function. ${ }^{11,12}$ Also surgical removal may become more difficult after migration. Infection is another well known risk of intra- abdominal foreign body. Tuncay et al, demonstrated abscess formation in migrated IUD. ${ }^{13}$ Intra-abdominal actinomycotic infection related to mislocated and migrated IUD has also been reported. ${ }^{14}$

Finally, removal of perforated IUD is important from the medico- legal aspect. Patients anxiety after diagnosis of a foreign object in their abdomen and their assumption of an incorrect IUD insertion by the health care provider may lead to medical malpractices claims. ${ }^{15}$

Laparoscopic removal of migrated IUDs is currently recommended. In our series, all migrated IUD were removed using minimally invasive approach. Laparoscopy was performed to remove intra- abdominal IUD in three cases. Cystoscopy was required in one case and the remaining two were removed successfully, hysteroscopically. In a recent study by Balci et al, laparoscopy was performed in all the patients using single or double ancillary ports with successful removal of migrated IUD. ${ }^{16}$ Colonoscopic removal of transmigrated IUD to colonic wall has also been reported. ${ }^{17}$ Although, minimally invasive technique is preferred approach to remove mislocated IUD, some clinical situation like presence of extensive adhesions, bowel obstruction, bowel perforation or severe sepsis may warrant use of open transabdominal access by laparotomy. Rates of successful laparoscopic removal reported is variable from $44 \%$ to $100 \% .^{16,18}$ Adhesiolysis for extensive bowel and omental adhesions, in three patients of our study was performed laparoscopically. The advantages of minimally invasive approach includes, less post operative pain, shorter hospitalization, better cosmesis and quick post operative recovery. All our patients had excellent postoperative recovery. Our study is an effort to present our experience and data regarding successful management of migrated IUD, but the study is limited due to retrospective nature and small sample size.

\section{CONCLUSIONS}

In conclusion, our retrospective study demonstrates that minimally invasive surgical technique is very convenient, safe, effective and modality of choice to remove migrated IUDs. This approach is also useful in performing adhesiolysis when required with least postoperative morbidity. Misplaced IUDs should always be removed in symptomatic and asymptomatic patients. Additionally, to reduce the risk of migration, we recommend that insertion of IUD should always be performed by experienced person with sufficient level of training.

Funding: No funding sources

Competing interests: None declared

Ethical approval: The study was approved by ethical committee of Kasturba Hospital, New Delhi

\section{REFERENCES}

1. Dennis J, Hampton N. IUDs: which device? J Fam Plann Reprod Health Care 2002;28:61-8.

2. Heinberg EM, McCoy TW, Pasic R. The perforated intrauterine device: endoscopic retrieval. JSLS 2008;12:97-100.

3. Kassab B, Audra P. The migrating Intrauterine device. Case report and a review of literature. Contraception Fertil Sex 1999;27:696-700.

4. Daniel D. Dietrick, Muta M Issa, John N, Kabalin, et al. Intravesical migration of intrauterine device. J Urol 1992;147:132-4.

5. Marcovitch O, Klein Z, Gidoni Y, Holzinger M, Beyth Y. Extrauterine mislocated IUD: Is surgical removal mandatory. Contraception 2002;66:105-8.

6. Heartwell SP, Schlesselman S. Risk of uterine perforation among users of intrauterine devices. Obstet Gynecol 1983;61:31-6.

7. Darlong LM, Panda S, Topno N, Hajong R. Colonoscopic retrieval of migrated copper T. J Minim Access Surg 2009;5:40-2.

8. Mahmoud MS, Merhi ZO. Computed tomographyassisted laparoscopic removal of intraabdominally migrated levonorgestrel-releasing intrauterine systems. Arch Gynecol Obstet 2010;281:627-30.

9. Adoni A, Ben Chetrit A. The management of intrauterine devices following uterine perforation. Contraception 1991;143:77-81.

10. WHO mechanism of action safety and efficacy of intrauterine devices. Geneva: WHO; 1987 Pg. 48-63.

11. Caliskan E, Ozturk N, Dilbaz BO. Analysis of risk factors associated with uterine perforation by IUD. Eur J Contraception Reprod Health Care 2003;8:1505 .

12. Demir SC, Cetin MT, Ucunsak IF, Atay Y, Toksoz L, kadayifci O. Removal of intra - abdominal intrauterine device by Laparoscopy. Eur J Reprod Health Care 2002;7:20-3.

13. Tuncay YA, Tuncay E, Guzin K, Ozturk D, Omurcan C, Yucel N. Transuterine migration as a complication of intrauterine contraceptive device: 6 case reports. Eur J Contraception Reprod Health Care 2004;9:194-200.

14. Phuphong V, Sueblinvong T, Pruksananondak K, Taneepanichskul S, Triratanachat S. Uterine perforation with Lippes loop intrauterine device 
associated Actinomycosis: A case report and review of literature. Contraception 2000;61:347-50.

15. Grimaldi L, De Giorgio F, Andreotta P, D'Alessio MC, Piscicelli C, Pascali VL. Medicolegal aspects of an unusual uterine perforation with multiload $\mathrm{Cu} 375$ R. Am J Forensic Med Pathol 2005;26:365-6.

16. Balci O, Capar M, Mahmoud AS, Colakoglu MC. Removal of intra-abdominal mislocated intrauterine devices by laparoscopy. J Obstet Gynaecol 2011;31:650-2.

17. Gonenc M, Kalayci MU, Turhan AN, Deniztas C, Alis H. Endoscopic treatment of a transmigrated intrauterine device to colonic wall: a case report. Am J Obstet Gynecol 2011;204:e3-5.

18. Miranda L, Settembre A, Capasso P, Cuccurullo D, Pisaniello D, Corcione F. Laparoscopic removal of an intraperitoneal translocated intrauterine contraceptive device. Eur J Contracept Reprod Health Care 2003;8:122-5.

DOI: 10.5455/2320-1770.ijrcog20130607

Cite this article as: Sinha M, Gupta R, Tiwari A. Minimally invasive surgical approach to retrieve migrated intrauterine contraceptive device. Int J Reprod Contracept Obstet Gynecol 2013;2:147-51. 